FUTY Journal of the Environment, Vol. 3 No.1, July 2008

(c) School of Environmental Sciences, Federal University of Technology, Yola - Nigeria.. ISSN 1597-8826 STRATEGIES FOR THE CONTROL OF DESERTIFICATION

IN NORTHERN NIGERIA

\author{
Justus Eronmosele Omijeh, \\ National Research Institute for Chemical Technology, \\ (NARICT), P.M.B 1052, Zaria, Nigeria. \\ jeomijeh@yahoo.com 08059457403
}

\begin{abstract}
The Northern part of Nigeria especially the frontline states comprising of Bauchi/ Gombe, Borno, Yobe, Jigawa, Kano, Katsina, Sokoto/Zamfara and Kebbi which lie roughly North of latitude $12^{0} \mathrm{~N}$ face serious threats of desertification occasioned by over exposure of the fragile environment mostly through improper farming techniques, overgrazing by livestock and occurrence of frequent fires and drought. This ugly trend is further exacerbated by increase in the rate of fuel wood extraction especially by communities near to forest reserves due to high costs of alternative sources of domestic energy such as kerosene, gas and electricity. The need to maintain soils with stable structural aggregates which could contain more organic matter is crucial in combating desertification; hence choice of tree species to be used for shelter belt establishment is very important. Litters that drop from most leguminous trees decay and add more organic matter to the soil. Poor extension approaches and lack of adequate community participation in and adoption of tree planting technology and government's role in formulating and executing forest policies are some of the reasons why it has been difficult to control desertification in Northern Nigeria. Different extension approaches such as Training and Visit (T\&V), Training and Demonstration (T\&D), mass mobilization of people, use of electronic and print media can be incorporated into various agroforestry practices such as the scattered farm trees, silvi-pastoral and agro-silvi-pastoral systems, and shelterbelt establishment in order to help alleviate the problems of desertification in Northern Nigeria. Post planting maintenance of trees should be taught and encouraged among communities where trees have been planted. Government and some non-governmental agencies have proffered various suggestions aimed at stemming the menace of desertification but these are yet to yield results.
\end{abstract}

\title{
Introduction
}

Desertification is the reduction or destruction of the land's biological potential, finally resulting in the appearance of desert conditions. It is one aspect of the generalized degradation of ecosystem under the combined pressures of adverse and uncertain climatic conditions and overexploitation. This overuse has reduced or destroyed the biological potential, that is to say the plant and animal production for multipurpose use at the very moment when increased production was needed to meet the needs of the population aspiring to development, UNO (1977).

The problems of desertification are also experienced in some parts of Africa, Australia, Asia and the Middle East. According to estimates by the United Nations Environmental Programme (UNEP), desertification removes about 27 million hectares of land from agricultural production every year and is threatening more than one third of the earth's land surface of about 45 million $\mathrm{Km}^{2}$ bearing a population of about 850 million people, Hentyy (1986). Interventions by different agencies to solve these problems are yet to yield results. 
FUTY Journal of the Environment, Vol. 3 No.1, July 2008

(c) School of Environmental Sciences, Federal University of Technology, Yola - Nigeria.. ISSN 1597-8826

The geographical area of Africa susceptible to desertification is the Sahel region which stretches in a West-East direction from Senegal through Mali, Guinea, Burkina-faso, Niger, Nigeria and Chad to West Sudan, ICRAF (1989). The region is characterized by treeless landscape, sparse grasses and thorn bush interspersed with bare soil. The climate is highly variable with low rainfall and occasional extremes of temperature and humidity, Keay (1959).

In Nigeria, areas most severely affected by desertification are the semi-arid areas lying roughly north of latitude $12^{0} \mathrm{~N}$ and these fall within the Sudan and Sahel zones, Sagua et al (1987). These areas cover about 240,900 $\mathrm{km}^{2}$ and $20,700 \mathrm{Km}^{2}$ respectively, Kowal and Knabe (1972), amounting to 26.6\% of the country's area (fig. 1). The areas are characterized by scanty rainfall averaging $600-800 \mathrm{~mm}$ with great variation from year to year and a short rainy period of 100-120 days (Fig. 1).

Agroforestry is a land use system that combines food production or tree planting with agricultural crops and animals so as to get higher productivity, more economic returns and social benefits on a sustained basis than obtained from monoculture on the same unit of land Nair (1985). Some of the agroforestry approaches which could be helpful in desertification control include, the scattered farm trees, silvi-pastoral, agro-silvi-pastoral and shelter belts among others.

Practicing agroforestry in line with proper enlightenment of the various communities in these areas is essential in desertification control. Hence community-driven forestry extension packages could be incorporated in these practices. These extension approaches include various forms of training for forestry and extension workers, use of electronic and print media, introduction of forestry and extension concepts in school curricula and syllabi, use of the Agricultural Development Projects (ADPs) approaches of Training and Visit (T\&V) Training and Demonstration (T\&D), and the provision of incentives to people to encourage them to plant trees and maintain same.

This paper focuses on desertification in Northern Nigeria, its causes, consequences and suggestions on the use of combined strategies of agroforestry, sustained soil enhancement and improvement and forestry extension to control desertification. 
FUTY Journal of the Environment, Vol. 3 No.1, July 2008

(c) School of Environmental Sciences, Federal University of Technology, Yola - Nigeria.. ISSN 1597-8826

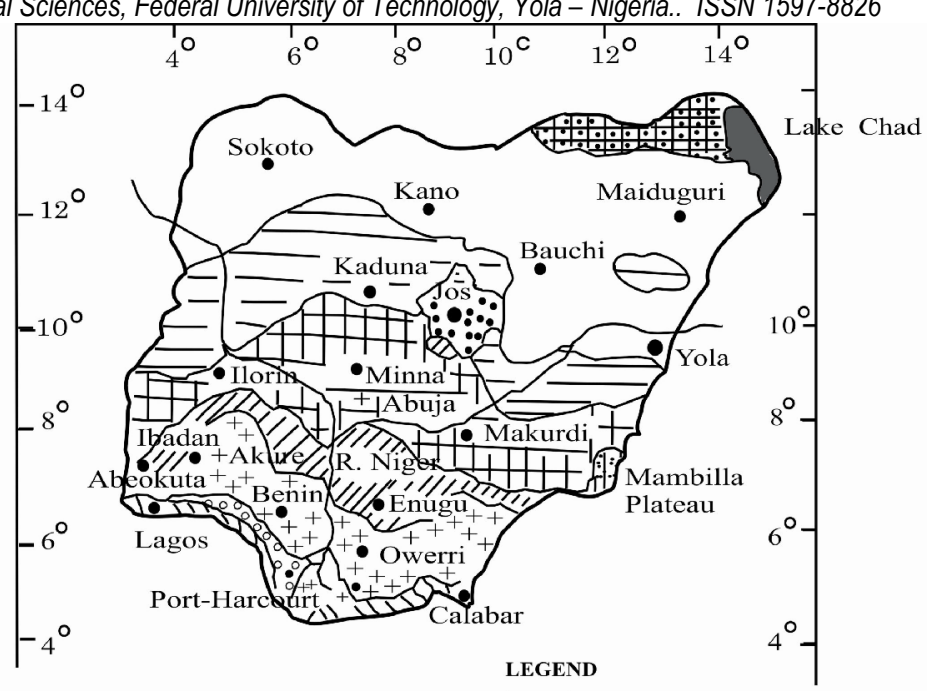

STATE

LAGOS

OGUN

OYO

ONDO

BENDEL

ANAMBRA

IMO

RIVERS

CROSS RIVER

KWARA

NIGER

NEW FSD. CAP. TERRITORY

BENUE

PLATEAU

GONGOLA

KADUNA

BAUCHI

KANO

SOKOTO

BORNO
STATE CAPITAL

Lagos

Abeokuta

Ibadan

Akure

Benin

Enugu

Owerri

Port-Hacourt

Calabar

Ilorin

Minna

Abuja

Makurdi

Jos

Yola

Kaduna

Bauchi

Kano

Sokoto

Maiduguri

洋: Sahel zone

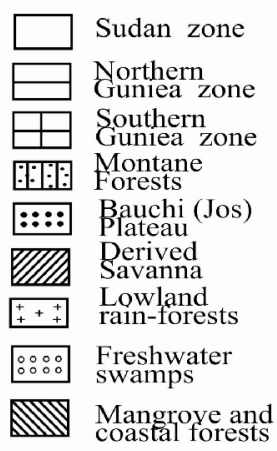

$0 \quad 190 \quad 380 \mathrm{Km}$

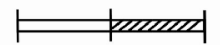

o $120 \quad 240$ Miles

* Only those states were indicated as at the time this map was drawn in

1985

Source: Keay (1959)

Fig. 1 Nigeria showing vegetation zones

Extent of Desertification in Northern Nigeria

Out of the 36 states of Nigeria and the Federal Capital Territory about 11 are seriously affected by various forms of land degradation. Each year they loose a large amount of land to desertification. Affecting each of these Northern states, desertification has emerged as Nigeria's leading environmental problem UNCCD, (1999). 
FUTY Journal of the Environment, Vol. 3 No.1, July 2008

(c) School of Environmental Sciences, Federal University of Technology, Yola - Nigeria.. ISSN 1597-8826 Table 1: Desertification in frontline states of Nigeria

\begin{tabular}{llllll}
\hline States & Population & $\begin{array}{l}\text { Land } \\
\left(\mathrm{Km}^{2}\right)\end{array}$ & area & $\begin{array}{c}\text { of } \\
\text { affected* }\end{array}$ & Nigeria \\
\hline Bauchi/Gombe & $\begin{array}{l}\text { Density } \\
\left(\mathrm{Km}^{2}\right)\end{array}$ \\
Borno & $2,294,413$ & 64,605 & 6.99 & 63 \\
Yobe & $1,411,481$ & 45,502 & 4.97 & 37 \\
Kano & $5,632,040$ & 20,131 & 2.18 & 31 \\
Jigawa & $2,829,929$ & 23,154 & 2.51 & 280 \\
Katsina & $3,878,344$ & 24,192 & 2.62 & 122 \\
Sokoto/Zamfara & $4,392,391$ & 65,735 & 7.12 & 160 \\
Kebbi & $2,063,226$ & 36,800 & 3.98 & 67 \\
& & & & 56
\end{tabular}

Source: Annual abstracts of statistics; facts and figures about Nigeria, Federal Office of Statistics (2000)

*Percentage of the state affected in relation to the entire Nigerian land mass.

Table 1 shows the rate of desertification in frontline states of Bauchi, Gombe, Borno, Yobe, Kano, Jigawa, Katsina, Sokoto, Zamfara and Kebbi which lie roughly North of latitude $12^{\circ} \mathrm{N}$ to the boundaries with both Niger and Chad republics. The extent and severity of desertification in Nigeria has not been fully established neither the rate of progression properly documented, hence any available data now may not be very accurate. Added to this is the fact that degradation of formerly productive lands in these states is a complex process which does not occur in linear, easily mappable patterns. In these states, deserts advance erratically forming patches on their borders hence it is virtually impossible to give the correct extent or measurement of the movement of the desert south wards, but the desert is surely advancing. The visible sign of desertification is the gradual shift in vegetation from grasses, bushes; and in the final stages expansive areas of desert-like sand. Entire villages and major access roads have been buried under sand dunes in the extreme Northern parts of Katsina, Sokoto, Jigawa, Borno and Yobe states. The pressure of the migrating human and livestock populations from these areas is absorbed by pressure points buffer states such as the Federal Capital Territory, Plateau, Adamawa, Taraba, Niger, Kwara and Kaduna states. Gombe 2003, revealed that Kano residents feared threats from the desert as the scourge has taken up to 25,000 hectares of farmland annually. Many factors are responsible for desertification.

\section{Causes of Desertification}

Oladipo (1993) asserted that two main factors are responsible for desertification in Nigeria (North inclusive). These include poor physical conditions in terms of soils, vegetation, topography and inherent extreme variability of climate as manifested in frequent droughts and secondly disruption in the ecological system caused by poor land use and the ever increasing demand being made upon available land resources by the expanding population and socio-economic systems. There is usually an interplay of complex interrelationship between social and natural factors in the ecosystem (fig.2). There have been frequent clashes between Fulani nomads and farmers in different parts of the country as cattle have been known to enter into farms to destroy agricultural crops. Overgrazing results in soil degradation, and erosion through soil exposure. As a result of poverty and difficulty of 
FUTY Journal of the Environment, Vol. 3 No.1, July 2008

(c) School of Environmental Sciences, Federal University of Technology, Yola - Nigeria.. ISSN 1597-8826

practicing shifting cultivation, many agricultural lands, are over exploited giving rise to

impoverished soils which find it difficult to support vegetation that could have helped to keep the soil structurally stable. Deforestation which is the depletion of tree crown cover to less than 10\% of its original state in any given area is happening at alarming rate in Northern Nigeria, Omijeh (2005). Trees are being removed from forests without corresponding replacement. Bush burning is a practice which is common among farmers who use it to prepare their land before commencement of farming, and nomadic cattle rearers in order to promote growth of grass for their cattle to feed on. Other causes of desertification in Nigeria include, ignorance, errors, natural and man made disasters and mistakes in choice of policies or technologies.

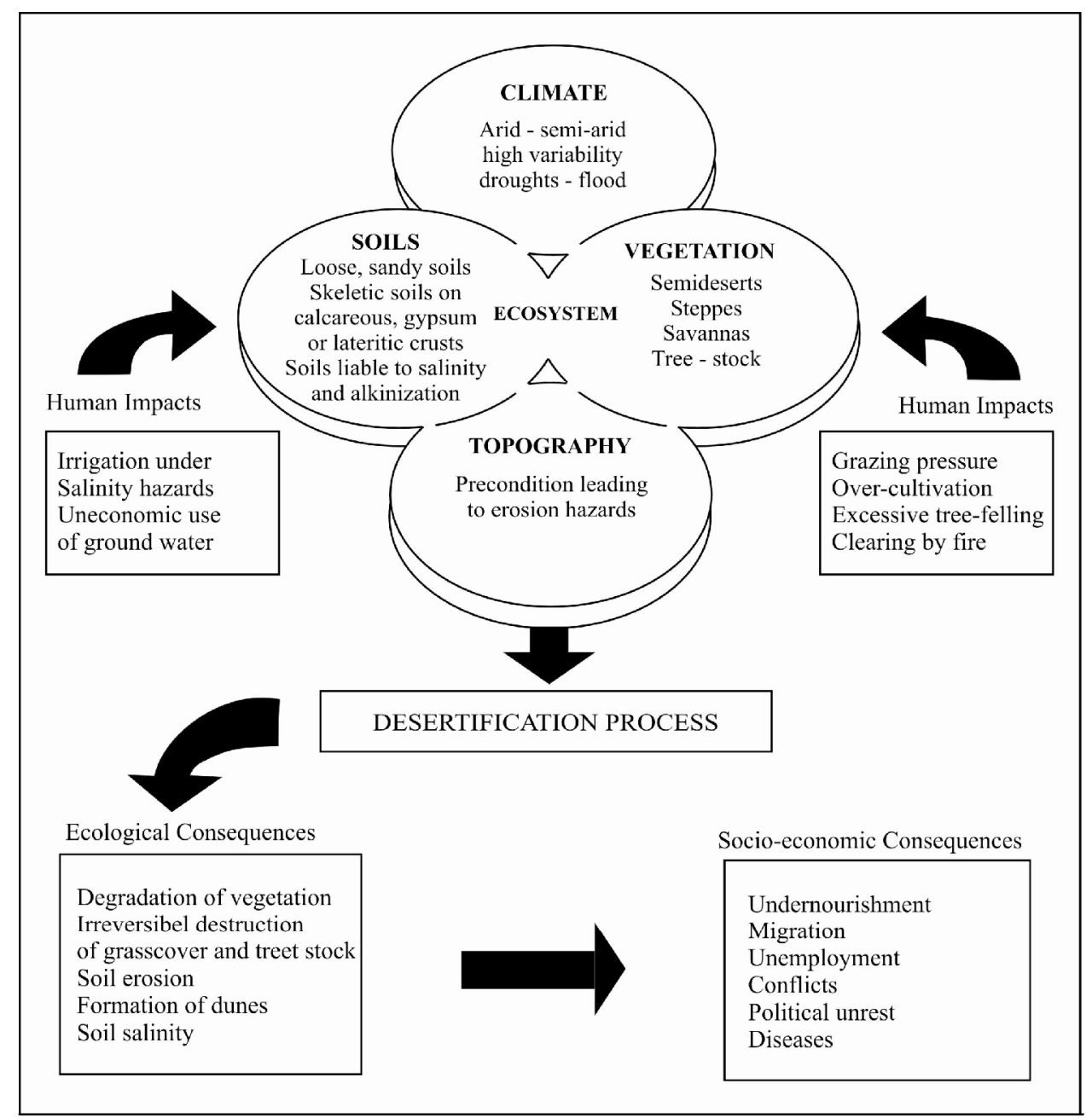

Fig. Model of desertification process (Adapted from Ibrahim, 1983).

The effect of climate change on desertification cannot be underestimated. According to Adeel (2007), tens of millions of people could be driven from their homes by advancing deserts particularly in Sub-saharan Africa and Central Asia because climate change is making desertification, "the greatest environmental challenge of our times". If action is not taken, some 
FUTY Journal of the Environment, Vol. 3 No.1, July 2008

(c) School of Environmental Sciences, Federal University of Technology, Yola - Nigeria.. ISSN 1597-8826

50 million people could be displaced within the next 10 years, U.N. reports (2007). Over exploitation of land and unsustained irrigation practices are making matters worse, while climate change is also a major factor degrading the soil, U.N. reports (2007). Desertification has adverse consequences on the ecosystem, Oladipo (1993).

\section{Consequences of Desertification}

Desertification has a lot of adverse consequences on the entire ecosystem as every component is usually affected. According to UNCCD (1999), the following result from desertification;

i. The land's resilience to natural variability is reduced. This is accentuated by sporadic spells of drought which pose serious threat to human existence. Drought is a state of climatic aridity, characterized by a marked absence of precipitation, which grossly affects the physiological functions of plants. It is a natural phenomenon which manifests as a period of water stress.

ii. Soils become less productive, and food production is undermined. With the desert lands covering adjacent agricultural lands, burying crops as they advance, the result is impoverished soils which eventually lead to low crop yield, hunger, famine and suffering among members of affected communities.

iii. Vegetation becomes damaged and forests become sparsely populated with the remaining trees exposed to the vagaries of harsh climate and other effects of the advancing desert.

iv. Social and economic costs are enormous, resulting in huge drain of economic resources, poverty, diseases, conflicts and even death.

v. Down stream flooding reduces water quality, sedimentation in rivers and lakes and siltation of reservoirs. To control desertification, some strategies will have to be adopted.

\section{STRATEGIES FOR COMBATING DESERTIFICATION}

\section{A. Agroforestry practices to control desertification}

The available methods applicable and to some extent already being practiced in most parts of Northern Nigeria include the scattered farm trees, silvi-pastoral, agro-silvi-pastoral systems and shelter belt establishment.

i. The scattered farm tree

This involves the retention of multipurpose tree species of economic importance on farm lands. The most common species within the derived savanna zone include, Afzelia africana, Brachystegia eurycoma, Detarium microcarpum, Irvingia smithii all with fruits used as soup ingredients, Okafor (1980)., and Elaeis guineensis with edible oil and nut. Other tree species retained for their timber value and mineral replenishment include Khaya senegalensis, Chlorophora excelsa, Antiaris africana, Terminalia superba and Terminalia ivorensis. The farm land can be further enriched by planting tree species like Gliricidia sepum, Acacia auriculiformis, or fruit trees like Mangifera indica, Psidium guajava, and Anacardium occidentale.

ii. Silvi-pastoral system 
FUTY Journal of the Environment, Vol. 3 No.1, July 2008

(c) School of Environmental Sciences, Federal University of Technology, Yola - Nigeria.. ISSN 1597-8826

This is the practice where woodlots or plantations are raised with fodder such as grasses to provide feeds for some livestock such as sheep, cattle, and goats. This eventually leads to production of wood and livestock products from the same piece of land. There is great potential for this system within the Northern guinea savanna zone especially where exotic tree species such as Eucalyptus tereticornis, Eucalyptus citriodora, Eucalyptus camaldulensis, Pinus caribaea, Pinus khasya which are not palatable to livestock are raised in plantations. The grazing animals usually feed on the grasses and some indigenous browsing shrubs within the plantations, thus helping to reduce the cost of weeding and fire hazards.

iii. Agro- silvi-pastoral system

This involves the raising of food crops, trees and livestock on the same land area, Nair (1985). It is practiced to a small extent in some parts of the savanna region, but it is more labour intensive though it encourages maximum utilization of land. Generally the animals are kept away from the farms during the farming season and fed in an enclosure (paddock) or may be reared to areas where grasses and browse plants are plentiful. After harvesting, the animals are released to the farms to feed on the crop residues. The system is yet to be fully developed in terms of plantation establishment. The most suitable trees for this system are the leguminous trees which are nitrogen fixing e.g. (some Acacias) and can therefore increase the soil nitrogen content for the growth of food crops in addition to providing fodder for livestock. Faidherbia albida is one of the most ideal species for this practice. It sheds all the leaves during the rainy season, thereby enriching the soil in addition to providing growing space for agricultural crops. It develops leaves again during dry season and hence provides fodder and shade for livestock.

iv. Shelterbelt establishment

Eucalyptus and Neem species are now used for afforestation in the savanna areas of Nigeria. Apart from provision of wood and wood products they are also used for shelterbelt establishment in the dry zones of the country. It involves the planting of rows of trees at right angles to wind directions adjacent to a farm land and on its wind-ward side. The areas of shelter belts established in Sokoto and Kano states stood at about $900 \mathrm{~km}$ (about 2,800 hectares) and 890km respectively, Namoda, (1985). A large scale shelter belt project was undertaken by the European Economics Community / Federal Government of Nigeria (EEC/FGN) joint afforestation programme in Katsina. 85 blocks of shelter blocks (each block made up of 6 hectares i.e $30 \mathrm{~m}$ by $200 \mathrm{~m}$ ) expected to protect about 3,400 hectares of farmland were established between 1987 and 1992, Uche (1989).

B. Post planting maintenance of trees.

Apart from the appropriate related technology transfer to people on tree planting achieved usually through extension packages, they can be sensitized on the need to develop proper maintenance culture for the trees that have been planted.

Oboho et al (1990) observed in the evaluation reports on afforestation programme of four local governments comprising Sokoto, Gwadabawa, Wurno and Isah in Sokoto state that though people responded massively for the year's tree planting campaign, postplanting maintenance of trees was very poor. Also, Yakasai (1990) reported that although 35 million of the 50 million tree seedlings produced between 1980 and 1989 were 
FUTY Journal of the Environment, Vol. 3 No.1, July 2008

(C) School of Environmental Sciences, Federal University of Technology, Yola - Nigeria.. ISSN 1597-8826

distributed freely to the general public for mass planting, the success of the tree planting campaign exercise was below average and lack of care of these seedlings especially against grazing animals.

Omijeh et al (2003) observed that about 94\% of farmers interviewed in Katsina state were actually aware of the annual tree planting campaigns organized by the government and fully participated in the exercise, but there was no significant correlation between the number of trees planted by the farmers and the socio-economic variables of age, income, family size, and level of education. They also identified the constraints to tree planting as inadequate supply of tree seedlings, high cost of fencing materials, watering and grazing problems.

\section{Extension strategies to control desertification}

According to Adegbehin and Omijeh (1991) agroforestry extension service can be intensified and made more effective through programmes such as organizing training courses for forest officers and field workers, farm broadcasts, circulation of relevant publications, mobilization of social groups, provision of incentives to farmers and employment of more agroforestry personnel.

\section{i. In-service training}

There are two main categories that can be trained in this regard. The first comprises the top level man power who could be trained by organizations such as Forestry Research Institute of Nigeria (FRIN), Forest Management Evaluation and Co-ordinating Unit (FORMECU), Project Co-cordinating Unit (PCU), National Agricultural Extension Research and Liaison Services (NAERLS). The second category could be for junior and intermediate personnel of forestry divisions of states and local governments and farmers.

\section{ii. Farm broadcasts}

The radio is best used in communication to communities because it has a wider coverage than other electronic media. Television and community viewing centres also go a long way in achieving this objective. Posters, extension guides, bulletins, flipcharts and news paper articles are print media which are also relevant in conveying messages to people on the need to plant trees and protect the forests.

\section{Mobilization or field approaches}

Model farms and demonstration plots help to display project package in a working context so that people can get the impact of the message.

Some non governmental agencies/organization such as British American Tobacco Company, Highland Tea Company are already involved in agroforestry, Adegbehin and Omijeh (1991), and many other organizations can be encouraged along this line too. Other field approaches include the mobilization of school children, individual and group extension, the ADP approaches of Training and Visit (T\&V) and Training and Demonstration (T\&D) systems of extension 
FUTY Journal of the Environment, Vol. 3 No.1, July 2008

(c) School of Environmental Sciences, Federal University of Technology, Yola - Nigeria.. ISSN 1597-8826

E. Edaphic considerations in combating desertification

Since trees grow on the soil, its enhanced ability to support vegetation is crucial in controlling desertification. Ezenwa (1983) observed the effect of nitrogen fixing plants on nutrient levels and the ability of such plants to modify and ameliorate the adverse physical conditions of soils; such soils contain more organic matter, their structural aggregates being more stable with much more additional leaf litter on the surface. The soil is thus made more resistant to the rain splash or heavy wind, also the rate at which moisture is lost from the soil surface in the season is reduced. Agroforestry tree species which will help in stabilizing the soil aggregates and having their decayed litters releasing and adding more nutrients to the soil for plant use are therefore very crucial in desertification control. Some of such trees, Faidherbia albida, Acacia seyal, Acacia niltica, Acacia senegal, Acacia auriculiformis, cassia sp. Leucenia sp. Dalbergia sissoo, and Tamarindus indica possess qualities of fast growth, good wood, yield gums and tannins and produce edible fruits and oils.

F. Other strategies for controlling desertification

i. Water resources management approach

This will involve the incorporation of an integrated land and water resources management approach to desertification, Odumosu (1998).

ii. Management of livestock grazing

Igboanugo (1991), opined that sedentary livestock production should be stressed as the best means of animal protein supply in order to check overgrazing of land.

iii. Use of opinion leaders

People in rulership, religious and community leaders can speak out against indiscriminate felling of trees and encourage tree planting by their various subjects.

iv. Local remedies

These include shelterbelt establishment, farm forestry, establishment of woodlots and plantations, stabilization of sand dunes through tree planting and establishment of life hedges.

\section{Government's efforts to check desertification}

The three tiers of government (local, states and federal) have made several attempts to check desertification. These efforts however, are yet to yield positive results. Obasanjo (2005) stated that the federal government of Nigeria would raise 5 million tree seedlings yearly for it's "greenwall" desert shield programme as part of federal government's contribution towards checking desertification in Nigerian cities especially in the Northern and semi-arid areas. Mande (2005) stated that every year his government (Yobe state) is involved in planting seedlings being raised and called on members of the public to compliment the effort of the federal government by planting trees to check the advancing desert. According to him, 10 billion naira was required to establish a perfect shelterbelt across the Northern region as a panacea to the fast approaching desert. Kachalla, (2003) proposed N1.1 b budget to fight desertification aimed at establishing 175 hectares of community woodlots and a watershed management programme in most local government areas of Borno state. The woodlots were 
FUTY Journal of the Environment, Vol. 3 No.1, July 2008

(c) School of Environmental Sciences, Federal University of Technology, Yola - Nigeria.. ISSN 1597-8826

to be established at Gwoza, Uba-Askira, Biu, Hawal, Shani, Kwaya-Kusar and Bayo council areas each having 25 hectares. In addition, 200 hectares of plantations of gum arabic seedlings and assorted tree seedlings were to be raised to fight and manage the rapid spread of desertification.

\section{Conclusion}

Desertification is threatening Northern Nigeria especially the frontline states, and this is mainly caused by deforestation, poor physical conditions, variability of climate, disruption in the ecological system, population pressure on available resources and socio-economic factors. These have adverse consequences on the entire eco-system which manifest in many ways which include impoverished soils and damaged vegetation, reduction in food production and huge drain on economic resources, conflicts among communities. The strategies proffered in controlling desertification include stabilizing the soil structure through the use of suitable tree crops, agroforestry practices, and the incorporation of relevant forestry extension approaches into these practices.

\section{Acknowledgement}

The author is grateful to his children who typed and word processed this script in the computer. All authors whose articles have been referred to are specially acknowledged. 
FUTY Journal of the Environment, Vol. 3 No.1, July 2008

(c) School of Environmental Sciences, Federal University of Technology, Yola - Nigeria.. ISSN 1597-8826

References

Adeel, Z (2007) United Nations issue desertification Warning. New Nigeria, 29 June, 2007 pg13.

Adegbehin, J.O. and J.E. Omijeh (1991) Agroforestry: socio- economic production and protective roles. Paper presented at a training course on Designing agroforestry activities for top managers organized by Afforestation Programme Co-ordinating Unit (APCU), Dorayi, Kano, $27^{\text {th }}$ March, 1991

Ezenwa, M.I.S (1983) Effects Eucalyptus camaldulensis shelterbelt in Aeolian soils of Sudan savanna. Pap. Presented at the $13^{\text {th }}$ Ann. Conf. For. Assoc. of Nig. Benin-city.

Gombe, A.S (2003) Desert threatens farmlands, Sunday Sun, 20 th July, 2003. Vol. 20 pg 38.

Hentyy, P (1986) The desert challenge and human response: Dimension and perceptions Ceres_No $110 \mathrm{vol}$. 9 (2), March-April 1986: 17- 24

Ibrahim, F.N. (1983) The role of nomadism in the process of desertification in Western Sudan. Appl. Geog development 22, $46-57$

ICRAF (1989) International Council for Agroforestry Research Working Paper No 28. 52pp.

Igboanugo, A.B.I. (1991) Agroforestry as a strategy to minimize effects of drought and desertification in Nigeria. Proc. of Nat. forestry workshop held in Kano. Aug. 6-9 ${ }^{\text {th }}, 1991$.

Kachalla, M (2003) Urgent need to fight advancing desert. The Guardian, Jan, $13^{\text {th }}, 2003$ pg51.

Keay, R.W (1959) An outline of Nigerian vegetation, Govt. printer, Lagos. 46pp.

Kowal, J.M and D. Knabe (1972) Agro-climatical atlas of Northern states of Nigeria. A.B.U. press, Zaria.

Mande, M. (2005) North needs N IObn for shelter belt. New Nigeria, May $9^{\text {th }}$ 2005. Front page.

Namoda, B.K. (1985) Development of techniques for sand dune fixation in the semi-arid areas of Sokoto state in; V.O. Sagua, E.E.Enabor, PRO. KIO, A.U. Ojanuga, M.Mortimore and A.E. Kalu (eds): Ecological disasters in Nigeria: Drought and desertification.

Nair, P.K.B (1985) Classification of agroforestry systems: ICRAF working paper no 28 Jan. 1985, Nairobi, Kenya 53pp.

Obasanjo, O. (2005) FG to raise 5 million seedlings yearly to combat desertification New Nigeria June $13^{\text {th }}, 2005$

Oboho, E.G., Okoro, S.P.A. and Kekanis, M. (1990) Evaluation of the success of tree planting campaign in arid zones as an aid to afforestation in Sokoto state. Proc. $20^{\text {th }}$ Ann. Conf. for. Assoc. of Nig. (FAN) Katsina, Nov 25-30, 1990 pp252-257

Odumosu, E. (1998) Combating desertification through operational hydrology. Fed. Min. of water resources, Garki Abuja 
FUTY Journal of the Environment, Vol. 3 No.1, July 2008

(c) School of Environmental Sciences, Federal University of Technology, Yola - Nigeria.. ISSN 1597-8826

Okafor, J.C (1980) Trees for food and fodder in the Savanna areas of Nigeria Int tree crops Jor. $1: 131-141$

Oladipo, E.O. (1993) A comprehensive approach to drought and desertification in Northern Nigeria. Natural hazard_ 8: 235-261 Pub. Kluwer academic publishers

Omijeh, J.E. (2005) A review of deforestation and forestry extension efforts in Adamawa state. SAVANNA, vol.20 (1) Jor. Env. and Soc. Sc., Ahmadu Bello Univ. Press Zaria. 9pp.

Omijeh, J.E, J.O. Yahaya, J.O. Adegbehin, E.I. Arifalo and S.O. Othman (2003) Response of farmers to tree planting campaigns in Katsina state. Nig. Jor. Agric Ext. 14 (1) pub. NAERLS/ ABU, Zaria. 15pp.

Sagua, V.O., E.E Enabor, P.R.O. Kio, A.U.Ojanuga, M. Mortimore and A.E. Kalu (1987) Ecological disasters in Nigeria: Drought and Desertification. Fed. Min of Science and Tech., Lagos. 386pp.

UNCCD (1999) United Nations Convention for Combating Desertification.

UNO (1977) Climate and Desertification. United Nations Conference on Desertification A/CONF. 74/5. Aug 29 - sept 9, 1977. Nairobi, Kenya P.I.

Uche, N (1989) EEC protecting katsina state with shelterbelts._The Guardian, April $18^{\text {th }}, 1989$ pg 12.

UNEP (1977) Desertification; Its causes and consequences. Oxf. Pergamin 448pp

UN (2007) United Nations issue desertification warning pub. New Nigeria. 29 ${ }^{\text {th }}$ June, 2007 page 13.

Yakasai, S.B. (1990) Management strategies for combating desertification in Kano state. Proc. For. Assoc. of Nig. Katsina, Nov. $25^{\text {th }}-30^{\text {th }}, 1990$ pp258 - 261 